to be hoped that this valuable work will be further developed, as it deals with a matter of the highest importance and interest.

We have finally to notice a most useful referencebook, "Tables of Refractive Indices," vol. i., "Essential Oils," compiled by R. Kanthack, which has just been published by the firm. A glance at the introductory list of 282 references to the widely scattered literature drawn upon in this compilation is alone sufficient to emphasise the value of the little volume.

We shall look forward with great interest to further additions to this first list of the achievements of the scientific staff of Messrs. Adam Hilger, Ltd.

$$
\text { A. E. C. }
$$

\section{A NEW BRITISH WHALE.}

R. S. F. HARMER'S report on Cetacea stranded on the British coasts during igi 8 , published by the British Museum (Natural History), is one of quite exceptional interest to cetologists. Its most important feature is the announcement of the stranding during I9I7 of a specimen of the remarkably rare True's whale (Mesoplodon mirus). In his report for $19 \mathrm{r} 8$ this whale was recorded as Cuvier's beaked whale (Ziphius cavirostris) from Liscannor, Co. Clare. This was a quite pardonable error, since the skeleton reached the museum in a roughly cleaned condition, and displaying two large terminal mandibular incisors closely similar to those of a Ziphius. When the cleaned skull came to be examined, however, it became evident that a mistake had been made. This is the only male which has yet been recorded, and, so far, but three examples of this animal are known. The first recorded specimen, a female, was taken at Beaufort Harbour, North Carolina, on July 26, I912, and was described by the late Mr. F. W. True. It now appears that a third example is in the possession of the Galway Museum. This was taken in Galway Bay somewhere about i899. Some very useful measurements of the skull, a photograph of the mandible, and comparisons between the teeth of the Liscannor specimen and those of other species of Mesoplodon and Ziphius, add greatly to the value of this account. The mandible of Berardius, it may be remembered, bears two pairs of teeth, a pair at the extreme end of the mandible and a pair further back. Dr. Harmer suggests, and he is probably right. that the teeth of Ziphius, Mesoplodon mirus, and $M$. hectori answer to the anterior pair, while those of Mesoplodon bidens and allied species are homologous with the posterior pair.

Since each succeeding report adds greatly to the value of those which have preceded it, we trust that these annual summaries will long be continued, for they will add immensely to our knowledge of the migrations of the Cetacea of our seas. Already they show that some species are not so rare as they were supposed to be until this investigation was embarked upon.

\section{UNIVERSITY AND EDUCATIONAL INTELLIGENCE.}

Edinimgri.-A lectureship on the subject of organisation of industry and commerce is to be instituted, the endowment fund having been supplied by subscriptions from members of the following bodies: -Edinburgh Chamber of Commerce, Edinburgh Merchant Company, Leith Chamber of Commerce, Leith Shipowners' Society, and the Institute of Bankers in Scotland.

Prof. Pringle Pattison has intimated his resignation as from September 30 next of the chair of logic and metaphysics.

$$
\text { NO. } 2586 \text {, VOL. } 103]
$$

OxFord.--Several professorships which have been suspended during the war have now been restored by decree of Convocation. Among these are the professorships of logic, geometry, and experimental philosophy. An election to the latter has already taken place, as previously recorded in NaTuRE.

The preamble of a statute admitting women as candidates for diplomas in science and other subjects has recently been passed by Congregation.

On May 20 the same body accepted the preamble of a statute introducing many changes in the First Public Examination (commonly known as "Moderations"). Among these is the incorporation as optional subjects in this examination of mechanics and physics, chemistry, zoology, and botany.

THE Times announces that the sum of $200,000 l$. is being provided by the Victorian Government to enable Melboume University to complete its buildings.

APplicatrons for the filling of the chair of biology in the University of Melbourne, consequent upon the retirement of Sir W. Baldwin Spencer, are invited by the Agent-General for Victoria, Melbourne Place, Strand, W.C.2. The duties of the new professor will begin in March, 1920.

A Wireless Press message from New York states that Harvard University has raised a fund of $8000 l$. to found a scholarship, to be known as the Choate memorial scholarship, which will provide for the exchange of students between the American university and Cambridge.

A LIMITED number of free places tenable at the Imperial College of Science and Technology, South Kensington, are being offered by the London County Council to students capable of profiting by an advanced course of instruction. Applications have to be made upon special forms, obtainable from the Education Officer, L.C.C., Victoria Embankment, W.C.2, and returned by Saturday, June 14 .

THE University Court of the University of Aberdeen will in July, under the Georgina McRobert foundation, appoint a lecturer in pathology, with special reference to malignant disease. The lecturer should possess special knowledge of pathological chemistry, and will be expected to conduct research and to give instruction in subjects connected with his investigations. Applications for the post must be received on or before June 24 .

The regulations respecting the open competitive examinations (August, I92I) for clerkships (Class I.) in the Home Civil Service have now been published by the Civil Service Commission. The examination will be in two parts. The papers in Section A, which must be taken by all candidates, are:-Essay, English, questions on contemporary subjects, science, translation from one language. These all carry equal marks. In addition, there is a viva-voce examination which is valued as equal to three of the foregoing. In Section B a very wide choice of subjects is offered. In this there seems to be a fair balance, and ample opportunity is offered to students of mathematics or science. It is interesting to compare these regulations with the recommendations of Sir J. J. Thomson's Committee. They do not, for instance, require "all candidates to supply evidence of a continuous course of training in science extending over several years." They do offer some encouragement towards the study of the subject, though the extent of this will depend on two factors: reasonable opportunity for the student of science in the essav paper, and the appointment of a representative of science among the viva-voce 